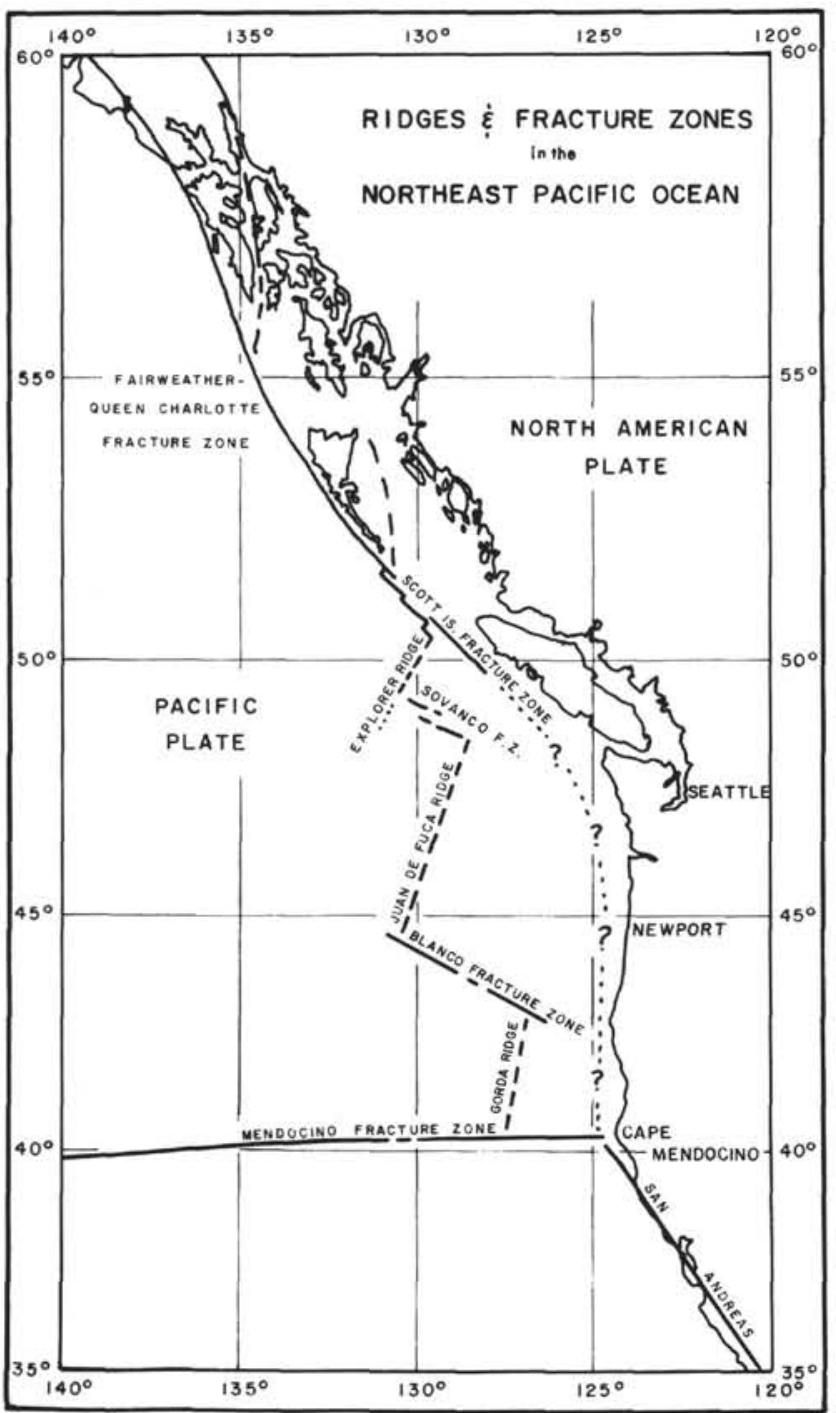

Figure 8. Tectonic map of the northeast Pacific Ocean showing ridge and fracture zone system in the vicinity of Site 177.

\title{
PART C: SITE SURVEY ON THE TUFTS ABYSSAL PLAIN
}

George Shor, John Grow, Harold Poelchau, Paul Liebertz, Robert Iuliucci and Sudi Karuse, Scripps Institution of Oceanography, La Jolla, California

Deep Sea Drilling Project proposed Site 18-8, on the Tufts Abyssal Plain, (not drilled) was surveyed by the R/V Melville from 7 July to July 10, 1970 (Figure 1). The site is located approximately $600 \mathrm{~km}$ west of the Juan de Fuca Ridge between the terminal ends of Moresby and Scott Channels (Figure 2). Regional magnetic studies suggest the site is near Anomaly 7 (Atwater, 1970). The site was proposed to study the biostratigraphy of the plain. Airgun reflection profiles and $3.5 \mathrm{kHz}$ echosounder records are used for stratigraphic interpretation of the area.

Topographically, the sea floor is essentially a flat plain dipping gently southwest with depths from 2260 fathoms in the northeast to 2295 fathoms in the southwest (Figure 3). Small nonlineated basement hills rise 50-150 fathoms 


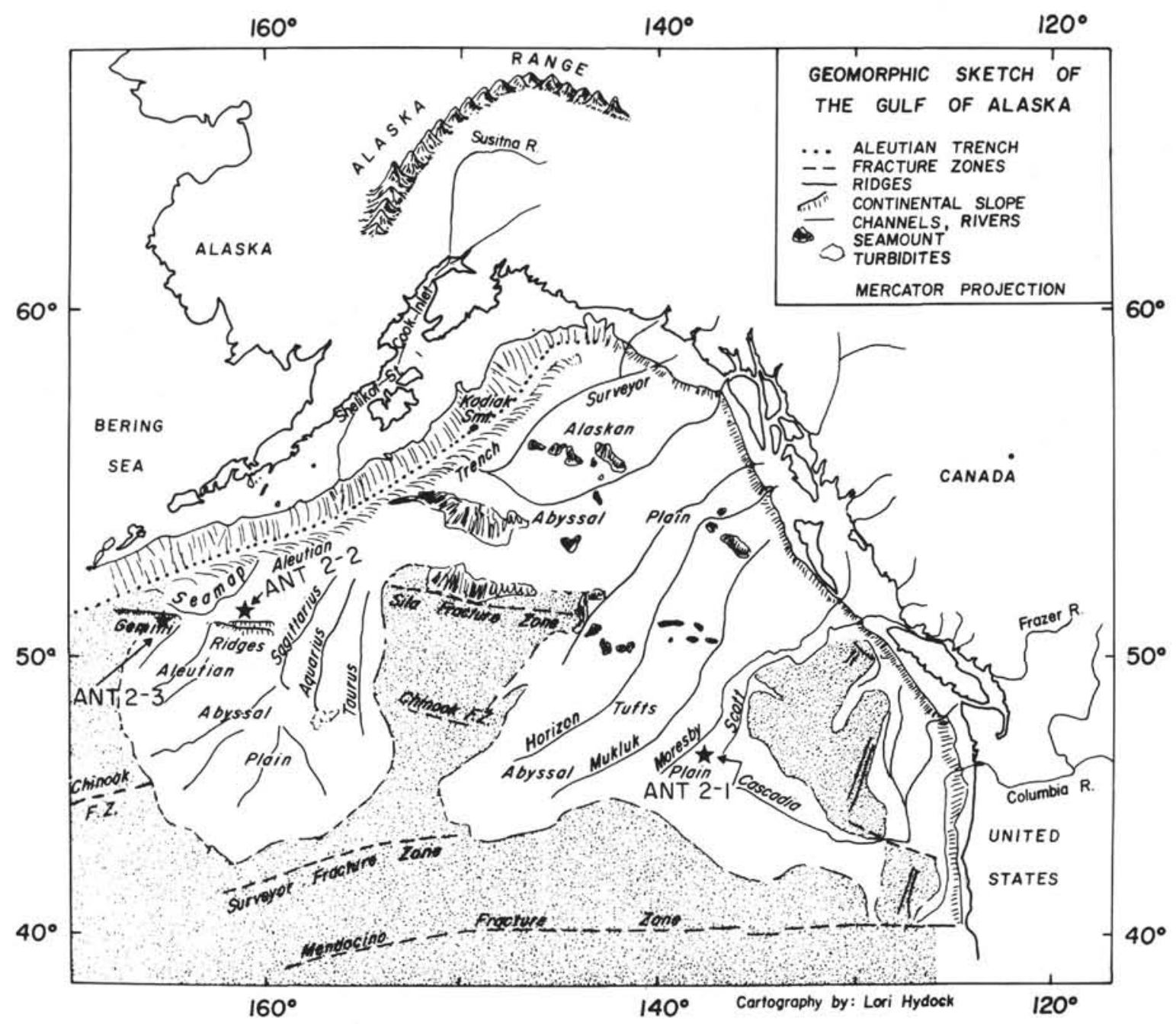

Figure 1. Regional morphology of Gulf of Alaska (from Mammerickx, 1970) with ANTIPODE Sites 2-1, $2-2$, and $2-3$.

above the bottom with a maximum relief of 350 fathoms. The reflection records show sediment filled troughs. (Figure 3) with distinct, continuous, flat-lying reflectors down to $0.3 \mathrm{sec}$ which are underlain by what appears to be transparent sediments down to basement. The transparent sediments are absent in areas where there is less than $0.3 \mathrm{sec}$ of penetration. The sediment troughs may have a northsouth trend. However, the particular trough which was surveyed in detail trends approximately $30^{\circ} \mathrm{W}$ of north.

A 30 -foot piston corer (ANTIPODE2-34P) was lowered at $46^{\circ} 39.9^{\prime} \mathrm{N}, 138^{\circ} 14.15^{\prime} \mathrm{W}$ at $0200-0400$ on 10 July where the records showed $0.4 \mathrm{sec}$ of penetration, but only $60 \mathrm{~cm}$ of sediment was recovered. The bottom barrel was bent at an angle of $5^{\circ}$ and the plastic core liner cracked. The sediment was interspersed with water bubbles and little sedimentary structure preserved. The core catcher contained a gray sandy clay which was overlain by a gray-green silty clay. An analysis of the catcher sample follows: angular quartz $(95 \%)$, dark heavy minerals $(2 \%)$, glauconite $(1 \%)$, clay minerals $(1 \%)$, organic matter $(1 \%)$. Approximately $0.5 \%$ of the sample was composed of radiolarians and only five individual foraminifera were found. No age determination was made. The sediment is well compacted and should yield the desired columnar section.

The magnetic anomalies in the site area range from -200 to +400 gammas and were weakly aligned in a north-south direction. Local anomalies, not obviously related to basement topography, were more dominant than the northsouth trends. The ship's track spacing was not sufficiently close to yield definitive magnetic patterns.

A trough, centered at $46^{\circ} 00^{\prime} \mathrm{N}$ and $137^{\circ} 51^{\prime} \mathrm{W}$ about 0.6 sec, was surveyed in greatest detail and is recommended as the primary DSDP site. Two alternative sites could be considered. The first alternative site is at $45^{\circ} 51^{\prime} \mathrm{N}$ and $137^{\circ} 42^{\prime} \mathrm{W}$ and was crossed only once on the initial track into Site 2-1. Its major advantage is that the airgun record was clearer than the others (ANT-6). The second alternative was at $46^{\circ} 21^{\prime} \mathrm{N}, 138^{\circ} 04^{\prime} \mathrm{W}$ and is similar to the others but the airgun records were slightly poorer.

\section{REFERENCES}

Atwater, T. and H. W. Menard, 1970. Magnetic lineations in the northeast Pacific. Earth and Planet. Sci. Letters, 7, 445 . 


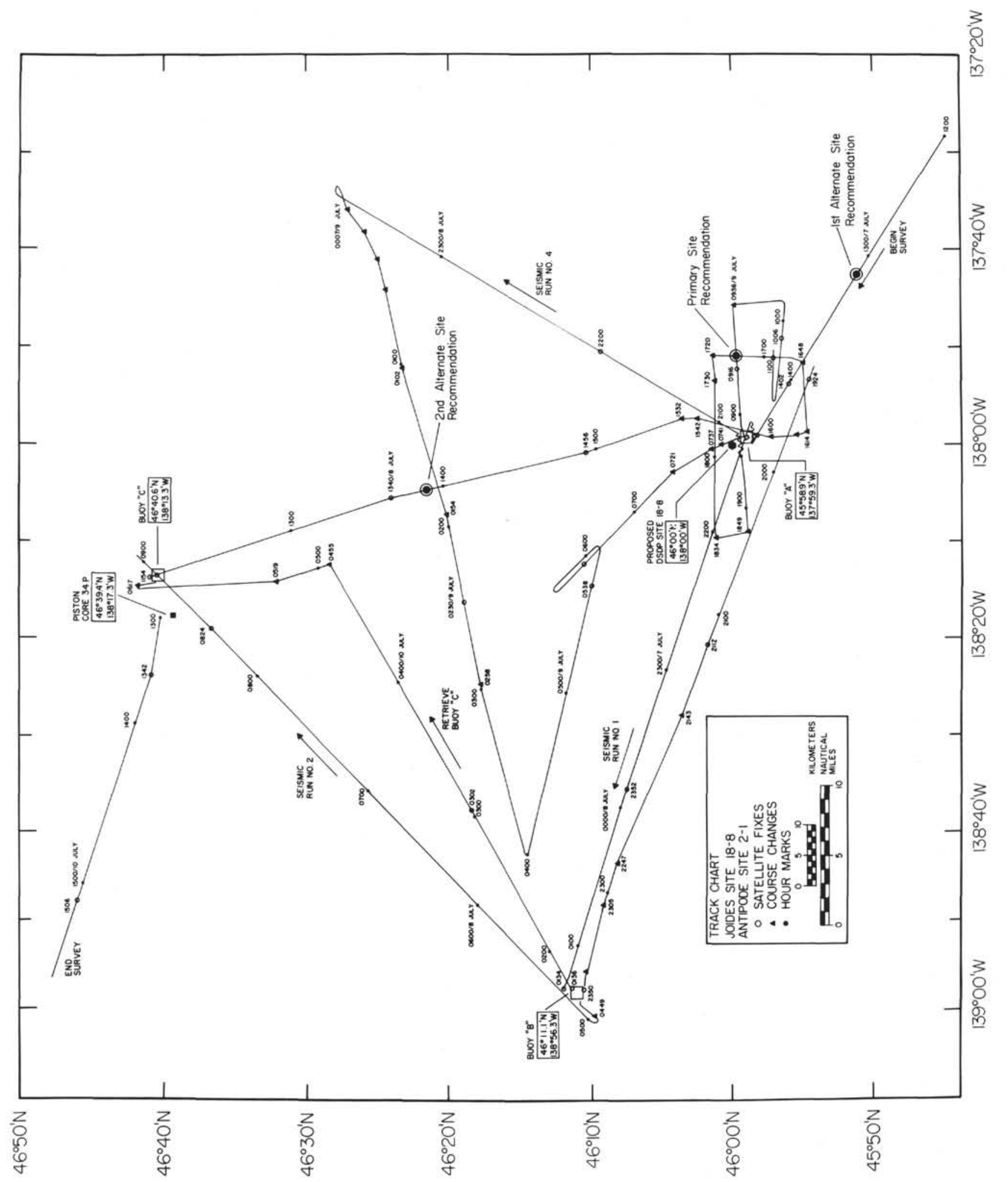

Figure 2. Regional bathymetry and track chart for Site 2-1. Small abyssal hills which protrude above plain are shaded with only the maximum elevation indicated.

Hamilton, E. L., 1967. Marine geology of abyssal plains in the Gulf of Alaska. J. Geophys. Res. 72, 4189.
Mammerickx, J., 1970. Morphology of Aleutian Abyssal Plain. Bull. Geol. Soc. Am. 81, 3457. 


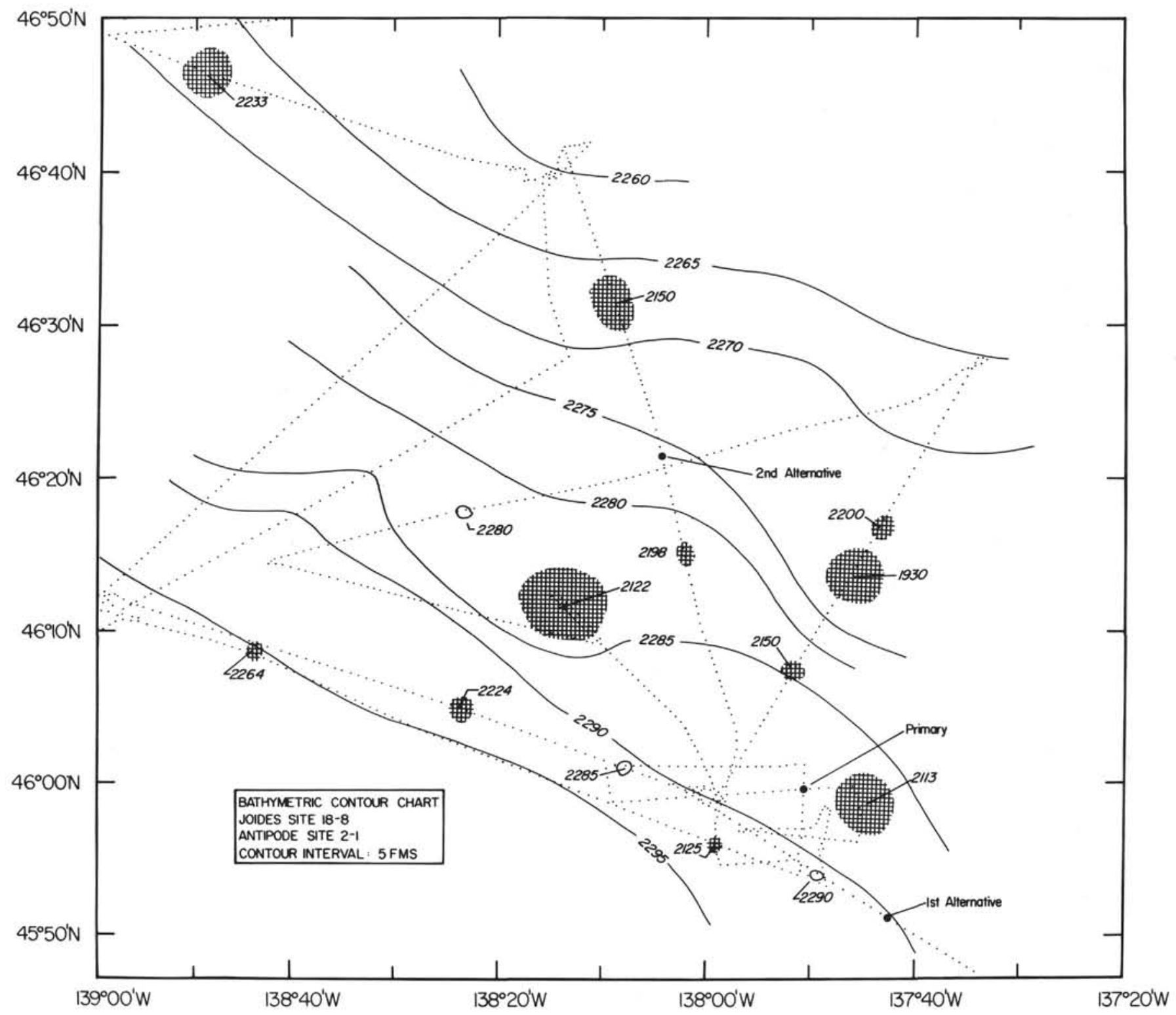

Figure 3. Detailed bathymetric map for Site 2-1. Small abyssal hills which protrude above plain are shaded with only the maximum elevation indicated. 


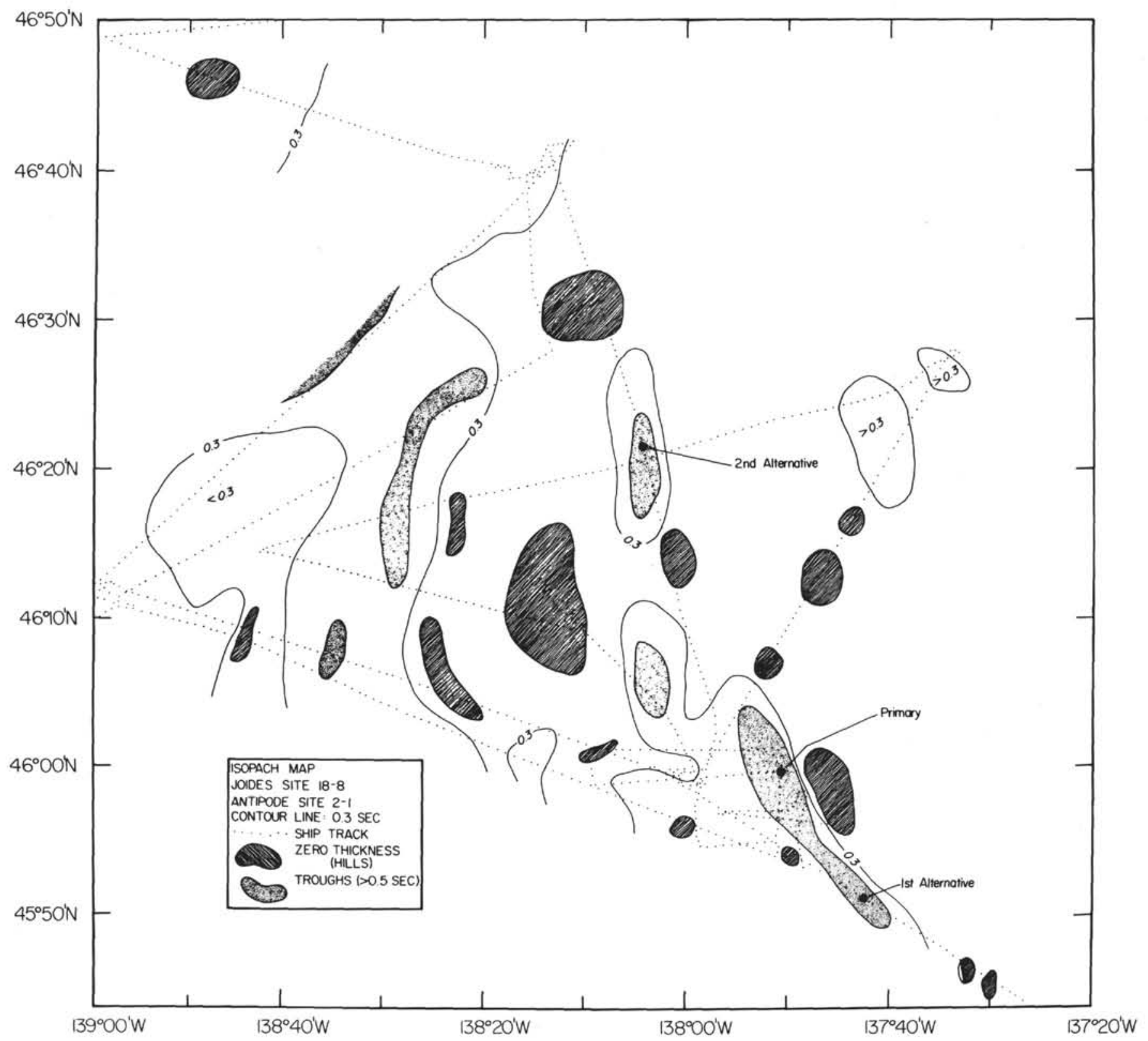

Figure 4. Detailed isopach map of sediment thickness for Site 2-1. 